\title{
Staff Manuals in College and University Libraries
}

In this paper Dean Louis R. Wilson of the Graduate Library School of the University of Chicago and his research assistant, Maurice F. Tauber, report their findings in a survey of 289 libraries.

A DMinistration and "management" are two dynamic terms which have replaced the passive "economy" in library terminology, and have been occupying consistently prominent places in the discussions of librarians. Heads of libraries have taken a cue from business and industry, and have observed and tested the values of such elements as planning, organizing, and staffing, and of such principles as departmentation, span of control, and delegation of duties. They have been attracted not only to the elements and principles of administration and management, however, but they have come to realize the utility of certain tools which have been successful as aids in the transference of theory into practice. One such tool is the staff manual, which, according to R. C. White, ${ }^{1}$ if carefully made, might present a picture of an organization in action, serve as a source for details of policies and procedures, offer a compact interpretation of the functions of the organization to employees scattered in various departments, and promote uniform

1 White, R. C. Public Welfare Manuals. American Public Welfare Association, 1937, pp. 3.4. understanding and practice in the organization.

With such potentialities as an instrument for improving the quality of staff activities and relationships, with resultant benefits to the clientele, it is not unexpected that librarians should join the movement to compile staff manuals for their particular institutions. Moreover, the staff manual has become a topic for consideration by students and teachers of administration. D. F. Deininger ${ }^{2}$ and Paul Howard, ${ }^{3}$ for example, have studied staff manuals minutely as administrative instruments in various types of libraries. Earlier, Margaret Hutchins ${ }^{4}$ and C. B. Joeckel $^{5}$ had discussed in briefer compass the advantages and various forms of staff manuals. Lucy E. Fay ${ }^{6}$ also wrote of the staff manual as a managerial tool in college libraries. All these students of the question of values in staff manuals reached the general conclusion that they are useful devices with which to facilitate the management of libraries.

\footnotetext{
2 Deininger, Dorothy F、 "Criteria and Methods for the Development of a College Library Staff Manual Applied to the Construction of a Staff Manual for Columbia College." (M.S. Essay, CoManual for Columbia College." (M.S. Essay, Co${ }_{3}$ lumbia University, School of Library Service, 1938.)
Howard, Paul. "Library Staff Manuals and a Theory of Library Management." (M.A. Paper, Graduate Library School, University of Chicago,

1939.) Hutchins, Margaret. "Staff Manuals." Library

Journal, 37:1039-42, Dec. I5, I932. Staff Instruction Book." Library Quarterly, 6:436. 38, Oct. 1936.

"Fay, Lucy E. "Staff Manual for the College Library." A.L.A. Bulletin, 31:464-68, Aug. I937.
} 


\section{Problem, Purpose, and Procedure}

The assumption, therefore, that staff manuals are helpful instruments of management was made at the beginning of a survey of manuals in a group of college and university libraries. Three points in relation to this assumption, however, were kept in mind. These were: (I) to learn the extent to which staff manuals are prevalent in libraries of institutions of higher education, (2) to discover if there is a positive correlation between the opinions of librarians concerning the need and practical value of staff manuals and the theoretical conclusions students have reached regarding them, and (3) to assemble as many copies of staff manuals as possible in order to build up a collection to be used in connection with library school courses in college and university library administration.

In the spring of 1940 a letter was sent to the librarians of the 33 member institutions of the Association of American Universities, and to the librarians of 235 colleges and universities and 2 I technological institutions on the A.A.U. approved lists. ${ }^{7}$

The body of the letter was as follows:

The Graduate Library School of the University of Chicago is endeavoring to build up its collection of general and departmental staff manuals of libraries. We should consider it a favor if you could supply us with a copy of your manual if it is available for distribution. In the event that there is a charge, please note the amount in order that we may place a formal order for the publication.

If your staff manual is not available for distribution, would it be possible for us to borrow and reproduce it? Or, if it cannot be sent to us, could arrangements be made for microfilming or otherwise reproducing it

7 Taken from the $193^{8}$ Report of the Association of American Universities. in your library or in a nearby library? What would be the probable cost?

In case you do not have a staff manual, or if for any reason you are unable to supply a copy, please indicate these facts for our information.

The extent to which librarians responded to this letter is shown in Table I.

TABLE I

RESPONSE BY LIBRARIANS TO REQUEST FOR MANUALS

\begin{tabular}{c|c|c|c|c}
\hline Libraries in & $\begin{array}{c}\text { Re- } \\
\text { sponded }\end{array}$ & $\begin{array}{c}\text { No Re- } \\
\text { sponse }\end{array}$ & Total & $\begin{array}{c}\text { Per Cent } \\
\text { Re- } \\
\text { sponse }\end{array}$ \\
\hline $\begin{array}{c}\text { A.A.U. institutions } \\
\text { Approved A.A.U. } \\
\text { colleges and uni- } \\
\text { versities }\end{array}$ & 30 & 3 & 33 & 88 \\
$\begin{array}{c}\text { Approved techno- } \\
\text { logical institutions }\end{array}$ & 195 & 40 & 235 & 83 \\
\hline Total & 244 & 45 & 289 & 84 \\
\hline
\end{tabular}

The reason for the large response doubtless is found to some extent in the request in paragraph three of the letter. There is, of course, a wide disparity between the number of responses and the actual existence of staff manuals (see Table II).

TABLE II

Staff Manuals in 244 College and University LIBRARIES

\begin{tabular}{|c|c|c|c|c|}
\hline Types of Manuals & $\begin{array}{c}\text { A.A.U.U. } \\
\text { Insti- } \\
\text { tutions }\end{array}$ & $\begin{array}{l}\text { Approved } \\
\text { Colleges } \\
\text { and Uni- } \\
\text { versities }\end{array}$ & $\begin{array}{l}\text { Techno- } \\
\text { logical } \\
\text { Insti- } \\
\text { tutions }\end{array}$ & $\begin{array}{l}\text { To- } \\
\text { tal }\end{array}$ \\
\hline $\begin{array}{l}\text { General manual } \\
\text { Catalog dept. } \\
\text { Circulation dept. } \\
\text { Document dept. } \\
\text { Order dept. } \\
\text { Periodical dept. } \\
\text { Reference dept. } \\
\text { Reserve Book dept.* } \\
\text { Staff Meetings } \\
\text { Student assistants' } \\
\text { manual }\end{array}$ & $\begin{array}{r}\text { I0 } \\
2 \\
3 \\
0 \\
\text { I } \\
0 \\
\text { I } \\
0 \\
0 \\
\text { I }\end{array}$ & $\begin{array}{r}28 \\
5 \\
9 \\
\mathbf{1} \\
4 \\
\mathbf{I} \\
2 \\
\mathbf{I} \\
4 \\
\mathbf{1}\end{array}$ & $\begin{array}{l}3 \\
\mathbf{I} \\
2 \\
0 \\
\mathbf{I} \\
0 \\
\mathbf{I} \\
0 \\
0 \\
0\end{array}$ & $\begin{array}{r}4 \mathbf{I} \\
8 \\
\mathbf{I} 4 \\
\mathbf{I} \\
6 \\
\mathbf{I} \\
4 \\
\mathbf{I} \\
4 \\
\text { I } 8\end{array}$ \\
\hline Total & I 8 & 72 & 8 & $98^{* *}$ \\
\hline
\end{tabular}

* Reserve book routines are most frequently included in circulation manuals.

** The difference between this total and the number of manuals acquired in the survey indicates the number of manuals that are not in suitable form for mailing or for reproduction.

\section{Extent and Nature of the Staff Manuals}

In his review of the Enoch Pratt Staff Instruction Book, Joeckel suggested that 
the publication of manuals of this sort for libraries of varying types should perhaps result in decreasing the need for intensive study of detailed routines and may permit greater concentration on the principles and objectives of library administration. ${ }^{8}$

Since many of the libraries have staff manuals in single typewritten copies, the distribution of these instruments to other libraries obviously is restricted. Although only 53 manuals of different types were acquired from 45 libraries during the survey, these figures do not represent a true picture of the actual extent of staff manuals in the entire group of libraries considered. This fact may be verified by consulting Table II, which shows the distribution of manuals. Approximately 40 per cent of the institutions have staff manuals of one type or another.

\section{"Typical" General Manual}

While it is difficult to speak of either a "typical" general manual or departmental manual, nevertheless, it is apparent that certain characteristics are common to all and the manuals differ only relatively. In his study of staff manuals, Howard classified the arrangement of staff manuals into four types: alphabetic, arrangement by departments, functional arrangement, and a combination of any of the other three. ${ }^{9}$ An examination of the general staff manuals collected during the survey reveals that the second type, arrangement by departments, appears the most frequently. The Oklahoma A. and M. College, the University of Nebraska, and the University of California manuals are examples of departmental arrangement.

The content of the general and departmental staff manuals likewise vary con-

8 Op. cit., p. $43^{8}$. siderably in both type and quantity of material included. General manuals, such as those of Kenyon College, Wheaton College, Flora Stone Mather College of Western Reserve University, and Antioch College, are examples of "typical" manuals. By contrast, the manuals of the University of Nebraska and the Oregon State System of Higher Education almost reach the proportions of the Enoch Pratt Staff Instruction Book.

The materials included in departmental manuals differ as the size of the libraries vary. Circulation department manuals, which are relatively common (Table II), range from the simple listing of desk routines to an almost complete description of activities which were treated by Brown and Bousfield. ${ }^{10}$ The manual of the University of Wisconsin circulation department, entitled Our Work, is an example of a highly detailed departmental manual.

\section{Manuals for Student Assistants}

The existence of a relatively large number of manuals for student assistants is probably to be expected. In many of the smaller libraries, the staffs of which often consist of a single professional worker, such manuals are indispensable media of instruction for a constantly changing body of student workers. This situation is not confined to small libraries, however, for large college and university libraries make considerable use of the efforts of governmentally aided students. The Bowdoin College Library Instructions for Student Assistants contains, in addition to local rules and regulations, material which is frequently found in student guides and handbooks to the library. The James10 Brown, Charles $\mathrm{H}$, and Bousfield, $\mathrm{H}$. G. Cir.
culation Work for College and University Libraries. American Library Association, I933. 
town College Library Notes to Library Assistants concentrates upon the actual duties and responsibilities of student workers.

\section{General vs. Departmental Manuals}

Whether a library should have a general manual instead of a series of departmental manuals is a question which was raised by a number of librarians. It is apparent that a combination of a group of departmental manuals, prefaced by general rules which apply to every person and all departments, will result in a manual for the whole library system. But is such a manual necessary, if departmental manuals exist? This question may be answered by saying that if the library is considered as a unit, the facts regarding activities and special tools of each department should be recorded and made easily accessible to staff members of every other department. The knowledge of such activities should facilitate the rendering of complete service to the clientele of the library. But some libraries have been content with merely a statement of staff duties and privileges. Instead of preparing a general manual including departmental procedures and duties, the Princeton University Library, for example, has issued a Staff Handbook, which describes in an interesting manner the responsibilities and privileges of staff members.

Of the 53 manuals which were acquired in the survey, 27 are mimeographed and 3 printed. A description of the forms of the manuals is presented in Table III. Of the 2 I typewritten manuals, 9 have been microfilmed for the Graduate Library School collection of staff manuals. ${ }^{11}$

Table IV throws light on the discrepancy between the number of librarians

11 See Bibliography at close of article.
TABLE III

Form of Manuals Represented in the Graduate LibRARY SCHOOL COLlECTION

\begin{tabular}{c|c|c|c|c|c}
\hline \hline Libraries in & \multicolumn{4}{|c}{ Form of Manuals } \\
\cline { 2 - 5 } & Typed & $\begin{array}{c}\text { Mimeo- } \\
\text { graphed }\end{array}$ & Printed & $\begin{array}{c}\text { To- } \\
\text { tal }\end{array}$ & $\begin{array}{c}\text { Micro- } \\
\text { filmed }\end{array}$ \\
\hline $\begin{array}{c}\text { A.A.U. institu- } \\
\text { tions }\end{array}$ & 4 & 4 & 2 & ro & 2 \\
$\begin{array}{c}\text { Approved A.A.U. } \\
\text { colleges and uni- } \\
\text { versities } \\
\begin{array}{c}\text { Approved techno- } \\
\text { logical institu- } \\
\text { tions }\end{array}\end{array}$ & r 7 & 20 & 0 & 37 & 7 \\
\hline Total & 23 & 27 & 3 & 53 & 9 \\
\hline
\end{tabular}

- The manuals in this column are not in addition to those recorded in the other three columns. In their original form, they were typewritten. Positive microfilm copies were made at the University of Chicago Department of Photographic Reproduction for the Graduate School collection which retains the negatives.

stating that they had staff manuals of some sort and the actual number for which copies were either sent to or prepared for the Graduate Library School. It is due to the large group of librarians who were reluctant to permit outside individuals to examine staff manuals that were neither completed nor in attractive format.

\section{Reasons for Nonexistence of Manuals}

As was stated earlier, the survey was started on the assumption that staff manuals are useful managerial instruments. Therefore, the reasons advanced by librarians for not developing staff manuals are worth analysis. For purposes of discussion, it may be said that the reasons center about three factors: (I) lack of faith in the value of the staff manual as a managerial instrument; (2) the use of substitute methods which are said to serve the purposes of the manual; and (3) lack of both time and funds for the preparation of the instrument. Each of these factors may be considered in more extended form.

The large majority of the librarians (see Table IV) who have expressed negative opinions regarding the value of the 
staff manual are associated either with libraries with large staffs (35 or more members) or with small staffs $(5$ members or less). Among the librarians of the large institutions who have disapproved of the staff manual in even semi-permanent form, the opinion is expressed that the instruments tend to crystallize action

TABLE IV

Manuals in Preparation and the Nonexistence of MANUALS IN 19 LibRaRies

\begin{tabular}{|c|c|c|c|}
\hline Institutions in & $\begin{array}{l}\text { Manuals } \\
\text { in Prepa- } \\
\text { ration }\end{array}$ & $\begin{array}{l}\text { No } \\
\text { Manual }\end{array}$ & \\
\hline $\begin{array}{l}\text { A.A.U. institutions } \\
\text { A.A.U. approved colleges } \\
\text { and universities } \\
\text { Technological institutions }\end{array}$ & $\begin{array}{r}10 \\
67 \\
5\end{array}$ & $\begin{array}{l}10 \\
76 \\
11\end{array}$ & \\
\hline Total & 82 & 97 & 179 \\
\hline $\begin{array}{l}\text { Manuals extant (See Ta- } \\
\text { ble II) }\end{array}$ & & & 98 \\
\hline Grand total & & & $277^{*}$ \\
\hline
\end{tabular}

* Several institutions had manuals of various types.

and thought, and thereby permit little freedom of expression of a professional attitude. In some of these institutions, however, the technical department, e.g. order and/or catalog department, devise working codes incorporating routinized practices.

In the small libraries, the attitude is concentrated about the uselessness of reducing routines and methods to written form for a staff that consists of from one to six regular members (the range of staff size in the libraries in which this feeling prevailed).

The opinions of librarians in large or in small institutions regarding the crystallizing effects of staff manuals must, of course, be considered on a logical basis. There is some evidence that rationalization enters into this type of an opinion. While this statement is not written in advocacy of staff manuals, it is apparent that it is not entirely consistent with logic for a librarian to decry the merits or demerits of a staff manual without ever having had one, or without ever working in an institution that had one.

There is no doubt that if a staff manual tended to crystallize thought and activity, its value would be reduced to a minimum. It is recognized at once that it would be unwise to permit a written code to elevate rules above judgment and professional experience. Whether a staff manual, or, for that matter, any practice or device of a library, becomes an effective instrument of management, or a set of hard and fast rules depends, in our opinion, upon the administrative officers and the attitudes they have developed among the staff members in regard to limitations of the tool. (There has been, of course, ample testimony to the effect that staff manuals have been useful devices.)

It will be observed from the letter that was sent to the librarians, no expression of opinion regarding either the merits or the demerits of the staff manual was requested. Yet, opinions pro and con were expressed, and they offer some evidence in an attempt to answer the second question that has been posed: Is there a positive correlation between the opinions of librarians concerning the practical value of staff manuals and the theoretical conclusions students have reached regarding them? The preceding comments in this section, plus the discussion that follows, may give some basis for establishing an answer to the query.

\section{Staff Manual for Small Staff}

What of the question of the need of a staff manual for a small staff, let us say, of one to six people? One librarian may be cited on this point:

Since our permanent library staff con- 
sists of two persons, the assistant librariancataloger and myself, we have not felt the need for a staff manual. I hope, however, that some time in the future a greatly needed enlargement of our staff may make such a manual necessary.

And students of staff manuals would say that such instruments are useful "before" the staff is enlarged. The point of view in the note of the librarian cited suggests that a manual is useful only to a staff of a certain size. It is further characterized by an apologetic tone which was present in a large number of replies from librarians who did not possess staff manuals for their institutions. Other librarians were more definite in indicating that a staff manual is not essential in a library with a small staff.

\section{Impermanence of Personnel}

It is evident that some librarians have not thought that the question of impermanence of personnel through accident, illness, or turnover is particularly serious. Of course, it is admitted that within a small group the chances for such occurrences are small. Yet, the testimony of several librarians, suggests that staff manuals may have value in the'management of a library that has but one, two, or a halfdozen professional librarians:

As I expect to retire soon, I am particularly anxious to leave a very workable booklet to which my successor can go on, and on which she may build.

I hope it (staff manual) would make the work easier for my successor than I found at the beginning at $\mathrm{O}$ - College with no record of procedures of the past. My experiences in going into a new library situation with no staff manual for a guide to the work of the library has surely made me realize the great importance of a good manual in every type of library.

Sometimes I get a little weary of com- piling these manuals wherever I go, but I have never yet inherited one from a predecessor. I wish the first-year library schools placed more emphasis upon the library manual, for until its importance is realized, there will continue to be all this lost motion which could so easily be avoided.

\section{Orienting the New Librarian}

It seems therefore, on the basis of actual experience of librarians, that the staff manual, regardless of the size of the institution, might be useful in orienting the new librarian. This may be objected to by some who would give the new librarian a free hand in his work, and not limit him with prescribed routines, procedures, decisions, or activities of his predecessor. If this is admitted, and it is, it still seems that a staff manual would be useful, even though it may be used as a guide for things not to be done.

It may be further argued that in small libraries-that is, libraries in which departmentation has not set in-duties group about the person rather than about the functions, and thus staff manuals are superfluous tools. There is no doubt that the staff manual in a library, just as the manual in a business or an industrial concern, becomes more useful as the size of the institution increases, as departmentation sets in, and when there is considerable turnover in the staff in the clerical and subprofessional as well as in the professional posts.

Perhaps undue emphasis has been placed upon the operations or activities of future librarians, rather than upon the present ones. Since Hutchins, Fay, Deininger, and Howard have described in varying degrees of detail the current uses to which staff manuals, or the information contained in them, might be placed, no minute review is necessary at this time. Charac- 
teristics of some of the manuals which were not accessible to either Deininger or Howard have been referred to earlier.

\section{Substitutes for Staff Manuals}

The second reason for the nonexistence of staff manuals in many college and university libraries may be observed in the various substitutes that librarians have devised to perform the services that are claimed for the formal instruments. Some of these substitutes are actually staff manuals in other forms.

First, there is the device of sending notices to the members of the departments with the understanding that the sheets are to be arranged according to an accepted outline. This procedure may gradually build up a staff manual. Such information as hours of opening, staff privileges, building rules, changes in cataloging procedure or other routines, may be contained in these notices.

A second procedure is to post notices on bulletin boards regarding changes in routines, activities, or duties. These notices are usually supplementary to general information given to members of the staff at the time of their entrance into the service of the library. Generally, they are administrative in nature, and do not encompass the large field of activity that either a general or detailed departmental staff manual attempts. If carried out in a systematic order, these bulletins, like the notices distributed to departments, may serve as a basis for a manual, if one is desired.

Card files form a third method of recording policies and routines. This is not a very common method for general staff manuals, however, and usually appears as a departmental record of decisions in the order and catalog divisions.

\section{Verbal Instruction Substituted}

A fourth substitute for the formal staff manual is verbal instruction. "Regular staff meetings" and "close and frequent conferences" are used to carry out orders relating to organization and routine. Small staffs do not have definite duties prescribed for the individual members, and work constantly overlaps. Thus each member of the staff knows, or is presumed to know everything about the library. For ordinary current work in a library of small size such a situation is not impossible, nor is the view regarding its merit to be discredited. As a sufficient reason for not recording essential activities, however, it poses three questions. (I) Does the body of knowledge concerned with the activities, routines, and procedures of a small library differ considerably from the content of courses that is assumed to be acquired by librarians during their courses in library schools? (2) Would not recourse to established textbooks, manuals, and codes that have been annotated serve the same purpose as a staff manual, except for details concerning local matters such as history, hours of opening, or staff privileges? and (3) When does a staff manual become-necessary for efficient procedure in a library? In response to the first and second questions, a considerable number of librarians would answer "no" and "yes" respectively. The third question is more difficult to answer categorically. It seems that the program of the college or university library will determine to a large extent what sort of information should be recorded. The extent to which a library engages in activities which are not included as standard practices in various codes and manuals will make it desirable to record these types of work if uniformity and consistency are the goals. 
It is apparent that routine tasks and operations, such as occur in the catalog, order, circulation, and periodical departments of the larger libraries, are more likely to be recorded than activities which require individual interpretation.

Some of the administrators of institutions which are in the process of reorganization or consolidation have refused to set down their work practices in the form of a staff manual, although they have noted that manuals are planned for the future. The reason for postponing the preparation of the instruments is the fear of making rigid certain information or procedures. The validity of this reason may be questioned on the basis of the experience of several other institutions in stages of reorganization or consolidation which have used staff-manuals for accomplishing work in a uniform manner. In a situation of this type, the principle of standard routines is closely followed. It is useful when, in a period of reorganization, several new staff members, professional and clerical, are added to the staff. A typical example would be reclassification and recataloging of the whole collection of books.

\section{Loose Leaf Manuals}

Staff manuals do not have to be rigid instruments. In a library that is growing in collections, personnel, and complexity of organization, a staff manual should be constantly supplemented and revised. Because of this fact, suggestions made regarding the maintenance of loose leaf manuals are worthy of consideration. ${ }^{12}$ The Oklahoma A. and M. manual, although printed and permanently bound, provides in an appendix a method and

12 See Howard, op. cit., p. 96 for a detailed discussion of the form of manuals. The maiority of the manuals are on pages $8 \pi / 2$ by II inches in size; the printed manuals are smaller in size. procedure for revising any portion of the work. Constant revision of manuals, however, may make printing less desirable than mimeographing. A printed manual, particularly if it is in a small edition and contains a large number of forms, is more expensive to issue than several other means of reproduction. The policy of duplicating staff manuals beyond the actual needs of a particular library may well be questioned.

Joeckel's recommendation concerning the need of staff manuals for various types of libraries in order to minimize the emphasis that has been placed upon detailed routines could be answered by the production of a few college and university manuals. Specimens already exist. The Oklahoma A. and M. manual is a good example of a college library staff manual. The library manuals of the University of Nebraska, Temple University, and the Oregon State System of Higher Education are three examples of detailed instruments which might serve as patterns for larger college and university libraries. The University of California staff manual is an example of a general manual that is not replete with minor departmental detail.

\section{Limited Time and Funds}

In a number of instances, librarians have explained the nonexistence of the manuals by reference to a shortage of funds and time. Time to prepare manuals, of course, is dependent upon sufficient funds. The excuse given by the librarians is probably legitimate. But so many librarians have acknowledged the values of staff manuals as managerial instruments that one might rightfully question whether or not the librarians not having them are spending their funds in 
the most efficient way. The feeling that staff manuals, if made at all, should be done at "odd moments" or "slack times" has been expressed by several librarians. This attitude, however, does not speak very highly of their importance when compared with other activities of the library. Staff manuals, of course, are worth the time put into them if they increase the efficiency of the work of the library in such a way that ultimately better service will be rendered to the patrons. Like other activities of the library, the preparation of the staff manual must be ranked in relative importance.

If the staff manual, however, may be utilized as a chart of the library organization and an interpretation of its service to the staff, the library administration, the president and the faculty, ${ }^{13}$ then it seems the administrator should allot library time for the preparation of the manual.

\section{Summary}

Although approximately 60 per cent of the librarians reporting stated that they had not developed staff manuals, only about Io per cent of this group actually expressed negative opinions regarding their value. On a purely quantitative basis, therefore, the opinions of librarians regarding staff manuals are significantly in favor of them as managerial instruments.

If we rely upon the experiences of this group of librarians, it seems safe to conclude that size of staff is not always the best determinant or criterion as to whether or not a library should produce a manual. Such matters as variations from standard practices, frequent turnover in staff (particularly if student help is preponderantly used), and interchange ${ }^{13}$ As many librarians believe. See Table IV. Approximately 40 per cent of the 244 libraries reApproximately 40 per cent of the 244 libraries re-
sponding either possessed staff manuals or had them in preparation. of staff among the departments must be considered.

\section{Collection of Staff Manuals}

A selected bibliography of college and university library staff manuals collected in the survey follows. It is not a complete list of staff manuals in all college and university libraries in the country, nor does it include manuals in preparation. Copies of all the items listed are in the possession of the Library of the Graduate Library School, University of Chicago. Negative films of the manuals produced on microfilm have been held in case libraries wish to have copies made. Positive copies may be obtained from the Department of Photographic Reproduction, University of Chicago Libraries.

A Selected List of College and University Library Staff Manuals in the Graduate Library School Library, University of Chicago. ${ }^{14}$

\section{General Organizational Manuals}

Antioch College. Library. Staff Manual. Yellow Springs, Ohio. 1939. (Mimeographed)

California. University. Staff Association. Staff Manual. Berkeley, Calif. I936. Ms.

Fisk University. Library. Staff Manual. Nashville, Tenn. 1937. (Mimeographed)

Lawrence College. Library. Staff Instruction Book. Appleton, Wis. 1940. (Mimeographed)

Oklahoma A. and M. College. Library. Staff Manual. 2nd ed. Stillwater, Okla. 1938.

Oregon State University. Library. Staff Manual. Corvallis, Ore. 1938-(Microfilmed from ms. copy) 14 Deininger's thesis contains bibliographical entries
of a number of departmental staff manuals of colleges, as well as a copy of the staff manual she leges, as well as a copy of the stafl
worked out for Columbia College. 
Temple University. Library. Sullivan Memorial Library Staff Manual. Philadelphia. I940.

Texas. University. Library. Library Staff Manual. Austin, Tex. 1936-(Partially mimeographed)

Western Reserve University. Flora Stone Mather College. Library. Staff Manual. Cleveland. 1935. (Mimeographed)

Wheaton College. Library. The Style Book of the Wheaton College Library. Wheaton, Ill. 1935. (Mimeographed)

\section{Departmental Manuals}

\section{Technical Departments:}

Montana. State University. Library. Catalog Division Manual. Missoula, Mont. 1938. (Mimeographed)

Nebraska. University. Library. Cataloging Department Manual. Lincoln, Neb. 1939. Ms.

\section{Service Departments:}

Nebraska. University. Library. Reference, Order, Circulation Departments: Manual. Lincoln, Neb. 1939. (Microfilmed from ms. copy)

Wisconsin. University. Library. Our Work: Circulation Department Manual. Madison, Wis. 1939. (Microfilmed from ms. copy)
Staff Instructions, Rules, etc.

General Staff:

Princeton University. Library. Staff Handbook. Princeton, N.J. I 935.

Western Reserve University. Library. Staff Manual-Rules and Privileges. Cleveland, Ohio. I930. (Mimeographed)

\section{Student Assistants:}

Birmingham-Southern College. Library. Information and Directions for the Use of Student Assistants. Birmingham, Ala. 1939. (Mimeographed)

Bowdoin College. Library. Instructions for Student Assistants in the Bowdoin College Library. Brunswick, Me. 1937. (Mimeographed)

Swarthmore College. Library. Manual for Student Assistants. Swarthmore, Pa. 1939. (Mimeographed)

\section{Schemes of Service}

Washington University. Library. Survey of Positions in the Ridgely Library of Washington University. St. Louis, Mo. 1939. (Mimeographed)

Western Reserve University. Library. Staff Manual-Salary Schedule. Cleveland, Ohio. 1940. (Mimeographed)

Staff Manual-Service Schedule. Cleveland, Ohio. 1940. (Mimeographed) 